\title{
Commoning the State Forest: Crafting Commons through an Indonesian Social Forestry Program
}

\author{
Haudec Herrawan ${ }^{1,2, *}$, Nurhady Sirimorok ${ }^{1,4} \odot$, Munajat Nursaputra ${ }^{3,4} \odot$, Emban Ibnurusyd \\ Mas'ud $^{3,4}$ (D) Fatwa Faturachmat $^{4}{ }^{-0}$, Andi Sadapotto ${ }^{3}{ }^{-}$, Supratman Supratman $3{ }^{3}$, Yusran \\ Yusran $^{3,4}$, Muhammad Alif K. Sahide 3,4
}

\author{
AFILIATIONS \\ 1. Doctoral candidate of \\ Forestry Science, Forestry \\ Faculty, Universitas \\ Hasanuddin, Indonesia \\ 2. Bila Forest Management Unit, \\ Province of Sulawesi Selatan, \\ Indonesia \\ 3. Forestry Faculty, Universitas \\ Hasanuddin, Indonesia \\ 4. Forest and Society Research \\ Group (FSRG), Forestry \\ Faculty, Universitas \\ Hasanuddin, Indonesia \\ * Correspondence: \\ bhh19m@student.unhas.ac.id
}

RECEIVED 2020-07-14

ACCEPTED 2021-11-18

COPYRIGHT @ 2022 by Forest and Society. This work is licensed under a Creative Commons Attribution 4.0 International License

\begin{abstract}
Studies of the commons grew out of responses to Hardin's bleak prediction of "tragedy of the commons," that without state intervention or privatization, any commons will eventually be destroyed by allegedly selfinterested users. As such, the commons studies traditionally tend to demonstrate cases where common pool resources (CPR) can be sustainably managed by groups of people beyond the state and market interventions. This paper shows a case from Sulawesi, Indonesia, where a state social forestry program can create a space for the program beneficiaries to build a commons. Through fieldwork that involves participant observation and indepth interviews with program extension workers and beneficiaries in two social forestry farmer groups, this study found that the program can stimulate beneficiary groups to build collective action in managing the state forest plots admitted to them and that the two groups are the only successful ones among 14 neighboring groups that are involved in the same program. The study also shows that the management of the statesponsored commons requires extension workers with deep knowledge about local people and landscape, economic incentives, and the flexibility of the local state agency in bending the rules based on bottom-up demands. Therefore, the case study shows that, on the one hand, the state program can actually stimulate the creation of the commons. On the other hand, commoning seems to be the only way to ensure a successful social forestry program.
\end{abstract}

\section{KEYWORDS}

Critical institutional analysis; commoning; design principles; institutional bricolage; Indonesia

\section{INTRODUCTION}

Studies of the commons grew out of responses to Hardin's bleak prediction of "Tragedy of the commons," that without state intervention or privatization, any commons will eventually be destroyed by allegedly self-interested users (Hardin, 1968). The leading proponents of the studies of the commons provide enormous instances from all over the globe on the ability of the resource users to get together and develop institutions to successfully manage their commonly held resource, the commons. Based on a multitude of case studies, Elinor Ostrom (1990) abstracted a list of primary conditions under which the collective users would be able to maintain the common pool resources (CPR) while enjoying sustainable benefits, namely the "design principles."

As a response to Hardin's prediction and solutions, the commons studies traditionally tend to demonstrate cases where commons can be sustainably managed by groups of people beyond the state and market interventions (Nayak \& Berkes, 2021). In addition, since Ostrom's CPR theory of commons divides the types of goods into public, private, and common goods, there is a tendency to neglect the private and 
public goods, or the hybrid types of goods as a site where commons can thrive (Turner, 2017). It is in this light that some current studies began to turn to the concept of 'commoning', which instead of focusing on the goods, or the property regimes, they pay more attention to a social practice that creates collective actions and institutions to manage a resource collectively regardless the type of goods they are governing (Bollier \& Helfrich, 2015; Euler, 2018; Fournier, 2013; Turner, 2017). By turning on another spotlight toward the commoning practices, instead of merely showing how common goods are managed, studies can begin to examine the roles of the state in the practice of commoning. Ryan (2013), for instance, began to specifically point out the ways in which the state can support and promote the common practices.

Nonetheless, through multitudes of case studies, Ostrom's theory of successful commons (Ostrom, 1990) is too robust to be abandoned. It is solid in identifying why a specific commons can be considered successful, understood here as those that bring sustainable benefits to the users while conserving the commonly held resources contingent to contemporary institutions, infrastructure, and natural resource conditions (Baggio et al., 2016). Ostrom's eight design principles can show us to determine whether a commons is successful or not. While retaining the principles to examine the case, this study will consider the challenges put forward by previous studies around power relations, cultural contexts, heterogeneity of rationalities underpinning the choice made by involved actors choice (Cleaver \& de Koning, 2015; Mosse, 2006; Mudliar \& Koontz, 2021; Saunders, 2014; Singleton, 2017). In other words, the principle designs will be unpacked with a critical institutionalism approach (Cleaver \& de Koning, 2015; Jones, 2015). Focusing on an Indonesian national government program, a Social Forestry (SF) scheme called 'community forestry' (Hutan Kemasyarakatan, HKm) in South Sulawesi province, this study will apply design principles and the critical institutionalism lens to look at the commons managed by the groups of farmers involved in the scheme.

Formal SF in Indonesia has undergone three distinct generations (Sahide et al., 2020), similar to the categorization of the formal period of SF identified by Fisher et al. (2019). The first generation of Indonesian SF during the authoritarian New Order rule explains the limited micro-scale and project-level SF engagements during this period. Meanwhile, the second generation grew out of political opportunities after the fall of the New Order government toward the end of the 1990s, which strengthened the national and international campaigns for more participation in forestry management. In the early stage, the second-generation SF was basically trial initiatives for future SF implementation that would help guide the regulatory processes, and therefore experienced funding provisions, field activities, and formation of farmer groups. However, while they are characterized by planting activities and promise for future income, studies described them as "tokenistic and procedural" while lacking material benefit-sharing (Fisher et al., 2019). They are pilot projects that are carried out to initiate longer-term state SF programming and were not pursued to devolve decisionmaking on land management. The third generation saw the rapid expansion of SF implementation, the development of new SF schemes and regulatory structure, especially since the first period of Joko Widodo's presidency (2014-2019). The SF areas have more than doubled up to 2 million hectares and continue to expand to reach the target of 12.7 million hectares to be granted rights for communities. However, this generation of SF again witnessed an "overwhelming focus on issuing permits" rather than the actual field implementation (Fisher et al., 2019). 
The study aims to examine how the SF program redistributes plots of state forestland, which opens an opportunity to groups of farmers to manage the resource collectively, and how they make use of the opportunities and go through multiple complexities to subsequently create commons through the practice of commoning.

\section{THEORETICAL FRAMEWORK}

CPR design principles explain the necessary conditions that characterize the likelihood of CPR management being long-enduring (Baggio et al., 2016; Ostrom, 1990). Subsequent studies to implement, enrich, and revise the design principles in various aspects. Studies have revealed, for instance, the missing question of power within the design principles (Mudliar \& Koontz, 2021); lack of examination of multiple rationalities underpinning the collective choice to govern the commons (Singleton, 2017); and embeddedness of the actors within various institutions and networks across different level often with different norms and interest, and therefore defy the view of homogeneity within communities of resource users (Agrawal \& Gibson, 1999; Cleaver \& de Koning, 2015). (Saunders, 2014) concludes that the CPR theory tends to be detached from the context since it explains the institutions governing the CPR more through actors involved in voluntary exchanges through mutual agreement and expect shared benefits than those in conflictual and unequal power relationships.

This study acknowledges the deep tension between "the assertion that sustainable resource-managing communities have existed since eternity (thus proving their effectiveness and viability), and the idea that communities or groups need to be created, their social capital developed and institutions crafted by outside stimulation and investment by the State or NGOs" (Saunders, 2014). However, we apply the principal design here as a way to analyze the extent to which the commons are healthy while considering its embeddedness in power relations, local norms, and the plurality of rationality (Cleaver \& de Koning, 2015).

In other words, while unpacking the design principles, this study adopts a 'critical institutionalism' approach (Cleaver \& de Koning, 2015) which explores several complexities around the commons. First, this study takes into account socio-historical and broader structural contexts of the commons. This research understands that a common can extend from local to the global system (Chikozho \& Mapedza, 2017; Jones, 2015; Saunders, 2014). Second, we recognize the interplay between formal and informal, traditional and modern arrangements. A commons can be managed outside of the state and private sphere, although it is open to state intervention to some extent (Bollier, 2014), or public goods typically managed by states (Harvey, 2011; Shaw, 2014). Third, the study considers the institutional complexities embedded in daily social life: as resource users/managers are socially embedded, this study delves into norms, values, and interests of different actors at different levels (Cleaver \& de Koning, 2015). Fourth, the resulting power relations can show internal exclusion within the proprietor groups themselves, which may or may not include users, since a commons is not always inclusive and progressive but can also be regressive and exclusive (Bakker, 2007). This study will not assume homogeneity within communities and pay attention to 'democratic political space' for the most marginalized group in decision making (Shaw, 2014). As Mosse (2006) argues, collective action can also be supported by ranked social relations and link to wider state bureaucracy levels that legitimize local authority and allocate productive resources. In this case, collective action can be successful while "embedded in wider systems of patronage and 
“corruption," as well as in village social hierarchies." (Mosse, 2006: 702).

In addition, considering the tension between long existed and newly built commons (Saunders, 2014), instead of applying the principles to analyze a traditional type of resource users, we delve into in situ institutional conditions developed in a deliberate social forestry program. Examining a newly built institution sponsored by an outside state program and NGO project, bringing in new types of rules and arrangement, and located within a state forest, would sit awkwardly with typical studies of the commons. It is true, at least for three reasons. First, traditional commons studies tend to examine long-standing commons governance developed by traditional resource user communities (Saunders, 2014). Second, by virtue of Ostrom's classification of goods--public, private, commons, club (Ostrom, 1990), the study of the commons put more focus on the common goods than the others and hybrid types of goods (Saunders, 2014). Third, based on the same classification of goods, commons studies focused more on the goods than the social practices that created the commons, the commoning (Euler, 2018).

Commoning is understood here as social practices that involve voluntary and inclusive self-organization and mediations in order to meet shared needs (Euler, 2018). Studies on commoning (or commonisation, see Nayak \& Berkes (2021)) emphasize the processes through which a group of people comes together to manage commonly-held resources to achieve shared objectives (Fisher \& Nading, 2020; Fournier, 2013; Sandström et al., 2017). As a collective social practice, the commoning includes co-produce rules that provide local services to face constraints, contribute voluntarily to satisfy shared needs, and create self-governing institutions where members directly affect each decision making (Euler, 2018). This shifts of focus from the goods toward the social practices in managing collective affairs, including the goods, also allow studying the commons governance in any type of property regime governing the commonly held resources. Moreover, (Nayak \& Berkes, 2021) pointed out an increasing number of hybrid types of goods with mixed property regimes managed by different groups of people as their shared resources. With this in mind, we propose adding studies on the commons that look at the public goods, in this case, to study the Indonesian government social forestry program in a state forest.

This case study focuses on two community forestry (HKm) groups in the Village of Mattirotasi (see Figure 1). The village is located on a stretch of 3,400 ha, on what used to be barren low hills in the province of South Sulawesi. The community forestry scheme has come to the village since 1999, first as a trial managed by Overseas Economic Cooperation Fund (OECF), a donor organization based in Japan. The Regional Watershed Management Unit (Balai Pengelola Daerah Aliran Sungai, here on BPDAS) then continued the trial project since 2002. Moreover, in 2012, the Ministry of Environment and Forestry granted formal use rights under a social forestry scheme of 'Community Forestry' (Izin Usaha Pemanfaatan Hutan Kemasyarakatan, IUPHKm) by issuing the ministerial decree (SK Menteri) to $14 \mathrm{HKm}$ farmer groups (Kelompok Tani Hutan) in the village. The two groups presented in this case study are Mattirowalie and Sipatuo 2. Mattirowalie currently has 28 members, and Sipatuo 2 is managed by 35 members. Despite the formal grouping, in reality, the two groups act as one, as the extension agent works for both groups (more below). 


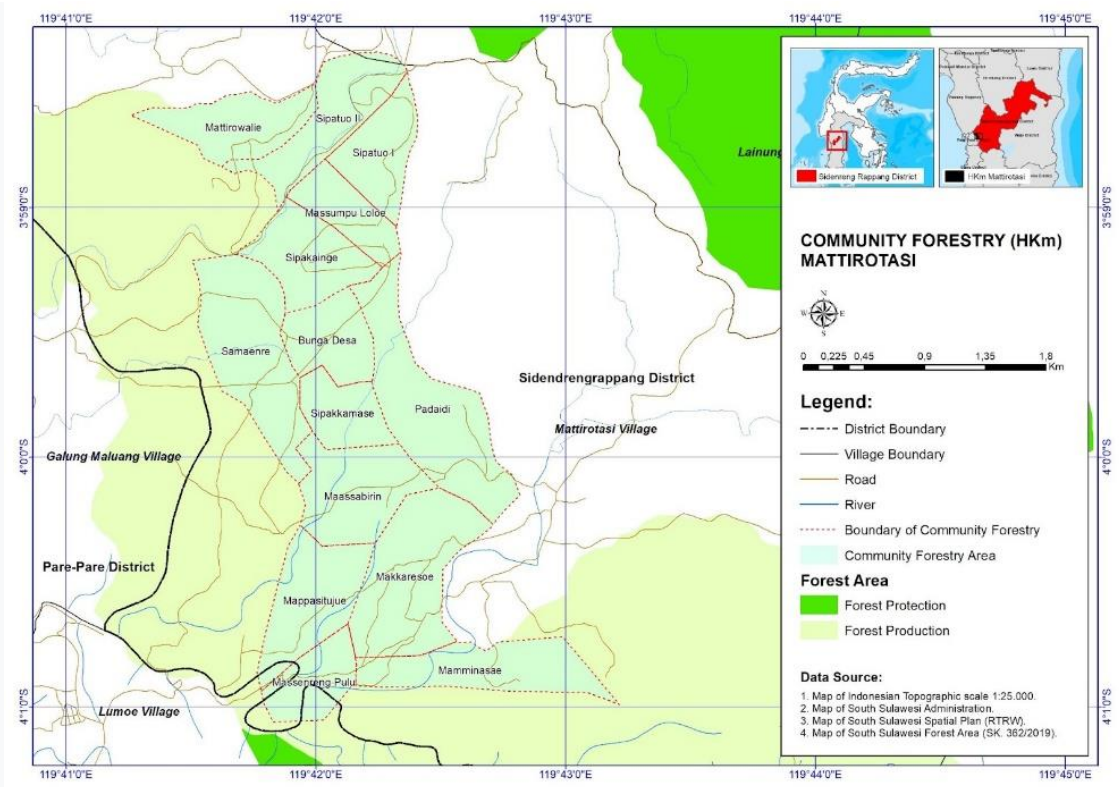

Figure 1. Map of HKm Mattirotasi

\section{METHODS}

We conducted participant observation, as the first author is an officer in KPH Bila who has served the office since 2019. Interviews and FGDs are carried out with the group members, village officials, and extension staff from July to October 2020. The collaborative fieldwork ensures that the first author's possible biases as a local forestry officer are revealed. The authors are fluent in local (i.e., Bugis) language, which helps build relaxed interviews and observation, probing, and understanding casual conversation.

Paraphrasing the design principles following this case study, these principles include (1) clearly defined forest and members boundaries, (2) congruence between local conditions and rules and between costs and benefits, (3) participation of group members in making and modifying rules, (4) The group rules are acknowledged and respected by higher authorities (5) develop own monitoring and accountability systems, (6) Graduated sanctions, (7) Affordable conflict-resolution mechanisms, and (8) Nested enterprise (Cox et al., 2010; Ostrom, 1990).

To fill the gaps in the design principles discussed above, following the Critical Institutional Analysis (Cleaver \& de Koning, 2015), we examine the broader context and historical formation of institutional arrangements currently governing commons. These include (i) the types of rules and relationships developed within and between actors operating at various scales, which includes 'institutional bricolage,' an ability of an institution to adopt new aspects and modify itself to serve as a multipurpose institution, (ii) interactions of norms, values, and interests among actors involved, (iii) the resulting power relation driving collective action among resilient communities (Cleaver \& de Koning, 2015). Exploration into these aspects establishes the necessary background that supports exploring the current forms of commons governance. 
In the next section, we will present a brief recent history of Mattirotasi commons, beginning with the start of a social forestry project in 1999, and on occasions reflecting on earlier situations to understand the background for the commons institutional arrangement. We will then examine the forest commons managed by the two HKm groups using the principle design while discussing multilevel relationships, norms, and values involved, as well as interests and power relations. We then conclude that the success of the Mattirotasi forest commons depends on several factors: the substantial economic benefits from the forest plots, mutually impactful interaction between the program and the local commoning, and the ability to build complex relations with the state, especially by a mediator, the extension staff who is also a group member

\section{A BRIEF HISTORY OF MATTIROTASI COMMONS}

The rise of the HKm groups in Mattirotasi characterizes the transition between SF's first and second generations. On the one hand, the SF was conducted as a community forestry project with the potential of formal follow-up programming by the state forestry agency. Here, the SF was initiated as a 'pilot project,' ran from 1999 to 2000 , covers 1000 ha of state forest, and is managed by the OECF). The project provided seeds and funds for the tree planting and the subsequent maintenance (run by a private company). The end result would be evaluated by a state agency (BPDAS Jeneberang-Walanae). While the local people granted plots of land within the program territory (state forest), they view the project as an important job opportunity that provides wages for their labor to plant the seeds and maintain the new trees. In addition, as one of the project's requirements, the local residents need to gather themselves in community forestry groups (Kelompok $\mathrm{HKm}$ ) to participate in the project. During the project implementation, the community groups were accompanied by an NGO and university staff. The project involved 500 families from three districts (Sidrap, Parepare, and Pinrang) adjacent to the forest area, divided into $20 \mathrm{HKm}$ groups.

Predominantly oriented toward conservation, the project assigns a composition of $70 \%$ timber trees and $30 \%$ of multipurpose tree species (mpts) to cover the HKm area. The HKm group planted timber trees such as local teak (Tectona grandis L.f.), Gmelina arborea Roxb, Swietenia mahagoni (L.) Jacq, Calliandra calothyrsus, Leucaena leucocephala; and mpts including cashew nuts, candlenuts, and mangoes. The conservation emphasis is also seen in the forest area chosen for the project. It was a marginal land dominated by savanna where cows are herded to graze. In fact, prior to the project, part of the area was controlled by private farms for cow production owned by local and national elites. Burning was also regularly seen in the area as the local people used the practice for varied purposes: slash and burn to clear croplands, heating the ground surface to ease the rocks digging to produce gravel, and chasing wild boar away from their croplands.

Prior to the OECF project, the local people considered the state forest area as croplands and grazing areas, and the monitoring was not so robust that it could crowd the people out of the land. The project then signified the start of the enclosure of the area: it sponsored the tree planting, which stimulated a multiyear program by BPDAS to nurture the trees, resulting in many parts of the forest being thickly covered with tree stands, so much so that the base can no longer be cultivated. At the completion of the OECF project in 2001, BPDAS Jeneberang-Walanae took over by first conducting 
an evaluation of the project's planting results, who then recommended that the trees are 'feasible to be maintained' in the next year's budget. Following the recommendation, the BPDAS conducted a multi-year program to take care of the planted trees from 2002 to 2005 and replace dead trees in 2006 and 2007.

The enclosure met with little resistance from the local people as they participated in the manual work of planting trees for a small weekly payment while enclosing their own grazing and cultivation lands. The local people see the planting as a wage labor project, and the resistance only arises when they ask for wage raises, and when their demand was neglected, around half of the group members went on strike. They simply stopped planting. There was little sense that they would receive any benefit from the trees they had planted.

In this context, an extension worker of the BPDAS project employed a different approach that stimulated better participation of the local people. He started work during the BPDAS project, a trial to community forestry management ( uji coba HKm), and was responsible for technical assistance for four HKm groups granted the Block 1 of the forest area under experiment. His efforts proved to be stimulating the group to participate in the aborted planting process, and in doing so, he created a new meaning of the community forestry project to the local people. In doing so, he initiated the commoning process. To be able to do so, however, he had to negotiate and bend some rules.

The scheme regulated that the forest should compose $70 \%$ of timber trees and $30 \%$ of multipurpose tree species (mpts). This ratio failed to attract the local people to end their strikes. The extension worker faced a challenging problem when trying to convince the group members of the future ecological and economic benefits of tree planting and tending. The people expressed that they could not see any benefit in participating in the project. Recalling their collective memories, they doubt that the trees would bring economic benefit. "Our parents did not give us seeds and all sorts of agricultural tools, nor did they pay us to plant trees. If that is the way, the harvest certainly will not be for us." The stories of people who are put behind bars for cutting trees they planted in the forest are widespread; or the stories of those who planted trees under government projects in their lands, by the forest, only to find several years later that they are no longer allowed to cut the trees. They were doubtful by the possibility that the government would actually grant them the forest for them to control.

Against this obstacle, the extension worker asked for a 2 ha plot from one of the group members, which was relatively easy since the member had little interest in the plot anyway. Weeding the land to prepare for the planting, he shows the local people that he will plant trees and harvest the produce and that they could do the same. He violated the rule that directed only group members to work on the land, but upon seeing his activity, the group member began to wonder whether the state had granted the land for them. He did not see any other way to convince the HKm group members to participate. When a few group members follow his example, clearing their plot to plant trees, they see him as a kind of insurance: "If the government will fool us. they would first have to fool their staff."

This dubious act of the government staff, and the people's reaction to it, demonstrate the complexity in the government day to day mechanisms that at times extend to illegal but seen to be licit activities (van Schendel \& Abraham, 2005). These practices are usually governed by certain types of informal institutions that require 
compliance from their participants, including those in formal offices (Helmke \& Levitsky, 2004). On paper, his action is illegal, but as it was usual for the people to see government staff own or use legally banned lands without consequences, their understanding was that the government staff action was legal, or at least it would be well protected or have certain legitimation in his local office (on varied state illegal but licit actions, see Aspinall \& van Klinken (2011) and Peluso (1992)). This HKm group members' understanding of such licit action seems to be stronger, in this case, it can convince them that the government staff action will ensure that the government would not invade their future harvest on their legally granted plots.

However, this action only solved one source of participation problem for the group members, that the government would not violate their grants. Another problem was to convince the group members that the economic return would justify their effort. This translates into the type of trees they will be able to plant in Block 1 . As noted above, the BPDAS program required the composition of $70 \%$ timber trees and $30 \%$ mpts. The extension worker had to negotiate with his superior at the BPDAS office to provide tree seeds in reverse order: $70 \%$ mpts and $30 \%$ timber trees. It would once again violate the rule, but he had two strong arguments to make. First, seen in total, the actually planted trees in the three blocks during the previous OECF project show a lopsided proportion of $80 \%$ timber trees compared to $20 \%$ mpts. Therefore, reversing the composition only in Block 1 , which is the smallest among the three Blocks, would not reverse the composition of the entire area under the BPDAS project. Second, the group members would not participate in the project without inverting the ratio, which would result in the project's failure. With such arguments and considering that the trial social forestry program was a showcase that could not be failed (Fisher et al., 2019), the superior agreed. The farmer members then mainly planted cashew on their own plots (more below), and today they produce approximately 700 tonnes of cashew nuts annually.

The second generation of social forestry is characterized by the shift from rehabilitation regime to the distribution of access rights (Fisher et al., 2019). In this case, the community forestry program distributes use rights for the people to access the state forest for 35 years. Out of the 1000 ha of the state forest involved in the previous rehabilitation pilot project area, only 750 ha was distributed to $14 \mathrm{HKm}$ groups. The definitive HKm groups were established in 2012 as a requirement for the rights distribution. The state forest distributed to them is legally classified as production forest (Hutan Produksi Terbatas), meaning they can actually harvest trees in the forest. However, experience and collective memory have taught them that cutting trees in state forests frequently requires complex procedures, even when one cut trees he planted. The farmer group managing HKm Sipatuo 2 received 45,25 ha, while the farmer group of $\mathrm{Hkm}$ Mattirowalie granted 39,3 ha.

In 2014 the group members began to breed livestock in the HKm area. It began when a few members noticed mutual symbiosis between the livestock and cashew trees. They found out that during dry seasons, when the grass volume typically reduced, the cows grazing in the area showed no sign of a decrease in size. It turns out that the cows consume the fruits that are attached to the cashew nuts (the locals call them "failed nuts"). In return, the trees seem to become more fertile as they receive a steady supply of manure from the cattle. After some meetings, they decided to collect money to gradually build a fence surrounding the whole groups' area for cow breeding. They set an annual contribution from each member (more below), buy barb 
wires, and work collectively to plant posts and extend the barb wires. The fence effectively keeps the cows in and animal intruders out and helps to keep their cashew harvest intact. They recently added a fodder barn inside the area to tap with increasing fodder needs. Last year approximately 200 cows were roaming inside the area, and there were signs that the area could no longer feed the population, so members took out part of their cows to reduce the stress. Today there are around 160 cows kept in the group's HKm area.

\section{DESIGN PRINCIPLES IN A COMMUNITY FORESTRY PROGRAM}

\subsection{Clear membership and plot boundaries}

While the land boundary was set since it was formally established as the HKm area before the OECF trial project, the membership boundary went through dynamics of membership changes. During the OECF programs, most of the original and recorded members of the HKm groups did not have an interest in managing their assigned plots and decided to neglect them. It was still the case at the termination of the project. As mentioned above, there are two reasons for the lack of farmers' interest: they did not believe that the government would keep their promise to let them cultivate the land, and some of the lands were covered with thick timber trees that defy any cultivation under the canopy. Learning from this past experience, in order to attract new members and to provide a sense of security that their future $\mathrm{HKm}$ plots would not be reclaimed by the government and the absentee members, the group develop an internal rule that new members who neglect their plots after six months will be replaced by yet the new one who are willing to obey the rule, by preparing and planting on their land as soon as possible. Since 2010, these dynamics began to settle for two reasons: financial gains and formal issue of the HKm grants. The proof of financial gains from the cashew nuts and cow breeding also explains the stability of membership since before formal signing of the groups. Since around 2010, most of the cashew trees have matured and the harvest brings a substantial amount of income to the members. This way the members are strongly motivated to maintain their rights for obvious reasons. The issue of the ministerial decree in 2012 brought more stability toward the group's membership. The decree formally grants the rights to the members to hold and manage the land for 35 years, which make it almost impossible to formally replace a member since it has to go through protracted and complicated procedures.

Only two cases of membership change were found after the decree was issued, and they occurred for another reason, being old and no longer unable to manage the land. In these two cases, the group decided that in one case, the land was transferred to a willing offspring of the formal member, and in another to a new member who is willing to pay for ganti rugi (remuneration). They also agree that the plots cannot be sold, and if the ganti rugi can be seen as selling, it certainly cannot be sold to "outsiders," which refers to someone who lives outside the village. This measure is done with no change made in the formal 'on paper' membership, and the other members have to agree on the inclusion of the new members on the ground that the new member is well known and seen as willing to be involved in collective works. The members can choose from a handful of candidates as the land has proven to bring lucrative gains.

Along with the memberships, the decree also specifies the boundaries and sizes of the plots they are holding. Since then, the land boundaries have achieved strong rights security to protect them from any other claims. There are a few cases when

Herrawan et al. (2022) 
certain people came, presented themselves as members of grazing companies working in the area in the past, and claimed to hold supposedly governmentsanctioned use rights to the land. The members-only need to respond by saying that they hold the HKm ministerial holders, and so far, it is always enough to send them away. In retrospect, one of the members said: "If they want us out, then first the minister would have to do so."

The land boundary, in actuality, was not immediately secure when the BPDAS program began. In the early stage of the cashew planting, the group experienced regular burning on the planted plots. The herders especially do the burning from around the village to stimulate the grass growth to improve pasture lands. This tradition regularly damages the newly planted trees. The herder would first search for suitable grazing spots with better grass potential and a relatively flat surface for easy access. Most of the $\mathrm{HKm}$ area in the two groups match these criteria. Upon finding the spot, they burn the remaining and drying grass at the end of the dry seasons and bring their livestock to the site when the grass is tall enough. The cashew trees were short enough to be partly invisible among the bushes and grass so that the herders could easily decide to burn the HKm plots. In an attempt to ward off the burning from the plots without provoking conflict with the herders, they needed a softer tactic. Here, the extension officer once again had to bend the rule by asking for a corn seed subsidy from the local agricultural office. Cultivating corn is illegal within a state forest area, and so it is reasonable that the agent needed to come repeatedly before the agricultural office granted them the seed. The group members then planted the seed at the edges of the HKm areas. It was a practice of "storytelling" in the broad sense of the word, a narrative that is understood and accepted by the local people that assert that the land has owners (Rose, 1994), and therefore can no longer be accessed by the herders, or any other claimants. The tactic successfully prevented further damage to the new cashew trees, and they only stopped planting the corn at the land edges when the trees were tall enough to be confused with undergrowth. After 2014, when the groups began to put their cattle in the HKm area, they gathered to administer another group rule for an annual contribution to building strong fences around the entire HKm area. With this, the narrative of land control becomes stronger and provides clearer area boundaries.

One important note here is that most of the members are rural proletarians. Prior to the program that granted them rights to the $\mathrm{HKm}$ plots, they were involved in casual jobs with daily wages such as construction worker, motorbike transporter, public transport (pete-pete) driver, hired as patrol by the grazing company, or similar types of jobs. They need arable land. Conversely, those who opt to neglect their plots typically have other plots outside the $\mathrm{HKm}$ and only intend to become absentee landowners through practicing 'ongko', controlling the land without actually cultivating the plot themselves. In a way, the uncertain nature of the HKm management in its early serve to select participants, distinguish the landless from the landed farmers.

\subsection{The congruence between rules and local conditions}

The second principle concerns the congruence between the rules and local conditions. In this case, the internal group rules are acceptable to the members, including their suitability to the benefits gained and local norms. The case shows a handful of rules they developed and enforced internally, and in some instances, also affected non-group members. We have seen above several rules such as no absentee 
members, no plot selling, annual contribution. In terms of annual contribution, the members decided in 2014 that they would pay IDR. 30,000 (approximately USD 2.5 in 2014 rate) per individual cattle aging one-year-old or older, paid for at the end of each year. The agreement was made to fund the fence building and maintenance, provide additional fodder and water for the cow in the dry season. They also agreed to pay an undetermined amount of incidental contribution should an immediate need arise, such as mending a broken fence. On top of these payments, they agree to provide labor for collective work such as fence building and maintenance.

They agreed to these rules and mechanisms because they are necessary to ensure the best possible production considering limited resources (such as grass fodder) and the ability to harvest the products. In total, they produce approximately 70 tonnes of cashew nuts annually and keep around 160 cows from their plots. The small amount of annual contribution cannot be seen as unwillingness to contribute to the shared interest since they pay more money and labor to solve the unexpected issues. This arrangement represents two aspects. First is the dominance of unexpected problems they have to deal with financial cost (regular monitoring is covered with labor contributions). Second, it may also stem from their deep-seated tradition of contributing labor, money, and goods in celebratory events related to the life cycle or incidental occurrences.

\subsection{Participation of group members in making and modifying rules}

"Meetings are plenty," said one member describing the early stages of each project, whether the ones that come from the government or their own. Convening group meetings has become their norm. The meetings are held for larger projects such as building the fence, or those related to outside parties, like proposing and welcoming government projects or subsidies. On this last note, the meeting norm ensures that the group can distribute the government information and subsidies evenly.

Besides the rules established during formal group meetings, others are produced from their informal gatherings and follow local norms. For instance, since the cashew trees began to bear substantial fruits, they made it their duty to watch each other's plots. During their evening outings, this rule agreed upon to hunt for wild chicken, after which they would consume the catch together while talking and sometimes spend the night in the woods. This practice is a local norm, also applied when they look for prawns in the streams. On one of such nights, they talked about the issue of cashew nut theft a member has experienced. Since then, they would call the plot owner if they saw a stranger come to the owners' plot. They would ask whether the owner had sent some worker to harvest (the sizable harvest of cashew typically requires most group members to hire additional wage workers). The caller would ask the owner to come and see the perpetrator had the owner reveal that he/she never sent a harvester. This mechanism also applied when they began to graze cows within the HKm area (see below).

The informal gatherings then are important occasions where the groups talk about shared issues. Cashew harvesting, for instance, provides opportunities for gathering in the $\mathrm{HKm}$ area while at times helping each other casually. It takes days to collect the fallen nuts, store them in sacks, and transport them to the main road. These agricultural-related gatherings accompanied and partly based on a tradition to conduct gatherings related to the life cycle, such as newborn (aqiqah), building and moving to a new house, wedding, and mourning the dead. The norm to hold gatherings 
helps the groups improve participation, including the women, in formal meetings related to the group activities and issues and the groups' rules making and modification. For instance, they have repeatedly talked about raising the annual contribution put forward by a few prominent members of the groups. However, because it would be too much for some members, they decided to stick to the same amount they agreed to in 2014 while paying for incidental contributions. This indicates a relatively equal relationship among the members, which helps to ensure equal participation.

The informal gathering also serves as an effective domain to identify issues brought up by members since the casual events provide a relaxed mood where everybody is comfortable enough to talk about their issues. Informal gatherings strengthen the bonds among members while preventing the creation of social distance, which can help in participation. During an FGD with the groups' members, it was clear that the women in the group showed little hesitation in voicing their opinion.

\subsection{The groups rules are acknowledged and respected by the higher authorities}

The group rules and rulemaking are acknowledged and respected by formal authorities outside of the group. There has never been a case where the government agents come and modify or annul group's rules. The ministerial decree granted to the group plays a vital role in this respect. The group has become a formal group acknowledged by the local and national state agencies, receiving more attention, including becoming a target for subsidies and other state services. They have received, for instance, aids in kinds such as seeds, agricultural tools, and equipment which includes 400 cashew nutshell crushers.

Their remarkable achievement as groups relative to other $\mathrm{HKm}$ groups in the area, mainly for their success in producing sizable harvest and collective management of the plots and cows, spotlighted them in the social forestry circle. Amidst pessimistic reports on implementing social forestry (Moeliono et al., 2017; Sahide et al., 2020), they become success stories. Visiting high forestry officials, forestry agencies, and social forestry groups from other provinces regularly come to Mattirotasi to learn about their recipes and achievements. Invitations to national events organized by forestry agencies also regularly sent the group representatives to talk about their achievements.

Lastly, the inclusion of the extension agent as one of the group members also serves an essential role in the acknowledgment. The extension worker has a better position to access contacts and information on programs, subsidies, and formal rules surrounding social forestry management. He can inform the whole group about changing and/or establishing traditional rules during the group's rule-making processes. This privilege enables them to work around and even bend the established formal rules that do not provoke adverse responses from government agencies.

\subsection{Develop own monitoring systems}

As mentioned above, the groups have developed systems to monitor the enforcement of the rules. They observe each other's plots and cows from theft, they watch for intrusion from non-members who try to lay claim on a certain plot. They assign members to ensure the financial contribution is paid on time and managed well. Many of these mechanisms are based on their long tradition of watching each other's property, such as land, plant, and cattle. They are incrementally crafted and 
enacted as group mechanisms upon experiencing a case of shared concern. An example is the case of a missing cow. A member noticed one evening that a cow was missing. He called other members, who immediately gathered and decided to block off all possible roads for the thief to take the cow out of the area. After waiting all night and realizing that the cow should have never been brought out of their plots, they decided to search the cow inside their perimeter and found the cow.

After the incident, the group members went to the field more frequently during the nights, and the same incident never recurred. One member said: "any potential thief will think twice to snatch our cows, since they think we are always on watch in the woods, for 24 hours, that we spend all night there, even when nobody is actually in the forest." In addition, they are ready to block off any possible escape routes for the cow thieves.

In general, as the members practice the mutual help norms, most of their monitoring mechanisms are applied to outsiders who try to take away their harvest or property. Since the monitoring mechanisms are based on local norms, they are not written on paper and spread through casual word of mouth. Violations done by members are usually unintended and are resolved through collective action, which we will turn to in the next section.

\subsection{Graduated sanction to rule violations}

Graduated and affordable sanctions developed incrementally through case-bycase events, enforced through collective action, and avoided adopting sanctions involving outside mechanisms such as financial fines or incarceration. This principle can be seen in cases where wandering cows have damaged the crops, and both the cows and crops owners are group members. In these cases, the victim will never ask for a financial settlement or other formal type sanctions. Instead, the available group members will work together to repair and improve the fence so that the accident will never be repeated. When asked why they avoid financial settlement, a female member said, "You may never get anyone to help you when you stand by the road with sacks you cannot carry and need to go back home." Or something of similar nature. They see financial punishment as a cheap move and that their relations and history (and potential) of mutual help are too valuable to lose by applying financial fines. A similar type of dispute settlement was found among ranchers in the case of people in Sahsa County, California, US (Ellickson, 1991).

Where the adopted (formal) sanction was applied or threatened to be applied, it was done toward non-members. A case in point is when a member's cows damaged a cultivated plot owned by a non-member who was a fellow villager. It was settled with financial payments, following the rule that the groups had agreed on. The group mediated the violation (the cow owner had failed to take care of his wandering cattle) and paid for the approximate cost of the damaged crops. However, the victim feels a mental burden after receiving the fine. Once, probably pushed by his burden, he asked the cow owners, "I have not seen you smile at me for a long time," to which the cow owner replies jokingly while smiling, "Why you are always in your car, and the road is dusty. All the dust would fill up my mouth if I smiled at you." As the norm of nonfinancial punishment upheld by the entire village, non-member villagers feel they should have chosen another kind of settlement.

The only cases where the adopted formal sanction was actually applied were related to the basic formal ties between the members and the group: their memberships. They were the cases where members were expelled from the group for 
violating the obligation to cultivate their granted plots after six months of controlling the land. This represents the end of formal relations between the members with the group. The rule was adopted to achieve formal requirements, namely, the distributed lands are planted with mpts, and therefore, it seems legitimate to punish the violators with related formal sanctions.

Another type of sanction involves the magical power of one plot owner that can render the thief to get lost in the seemingly open plots. The FGD participants recount a story where a cashew thief circled around in confusion within a plot all through the night in search of a way out until the owner finally came in the morning and freed him from the spell. The information about the incident, which is unfamiliar, quickly spread and seems to prevent similar violations effectively. This case represents another rationality as to why the people should avoid such violations.

\subsection{Affordable conflict resolution.}

As described in the previous section, the group mostly resolved disputes among members by avoiding financial compensations, and the group committee would mediate disputes between members and non-members. There has never been a case where the disagreement is so out of hand that they need an outside party to negotiate and settle the case for them. However, in the case of non-member violations, the threat of involvement of security forces is enough to resolve any potential dispute. For instance, a former member tried to reclaim the plot he held before his expulsion from the group for failing to cultivate the land. When the extension agent, who is also a member, heard the report, he came to meet him and said: "I heard that you have come to weed the land twice already. If you come once again, it will be the police who take you away!" This conversation was enough to stop him from attempting to reclaim the land. The agent-member explained that the man was his close relative, but "he had violated our rule in the past, and the punishment is permanent because we have redistributed the plot to another member."

\subsection{Nested enterprise.}

The group and the corresponding plots are established formally through social forestry scheme programming. This formal grant marks the inclusion of both the members and the land into a more extensive social forestry system in Indonesia. As such, the group receives more attention and subsidies. They are also invited to national events and host study tours to disseminate their success stories to other social forestry farmer groups. These involvements represent different levels of responsibilities for various parties, i.e., the group's commitment is to manage the granted land, and the state agency is responsible for supporting them and disseminating their success to other similar groups.

Along with their current high profile among the social forestry circle, the formal state grants are also critical to the protection of the commons, especially to face more powerful claimants, some are more powerful than the members. The ministerial decree is a formidable document to send away any potential claimants, thus convincing the group members to continue their activities on the granted plots. The inclusion of the extension worker in the group as a member, which is now formally allowed across the nation, provides additional leverage with better access to formal and more powerful conflict resolution mechanisms. 


\section{DISCUSSION: COMMONING THE STATE FOREST}

The formal social forestry schemes are part of the result of ongoing international and national advocacy on land access and community-based resource management. The state land distribution programs developed and persisted so far can be seen as part of the result of the national and international agrarian reform, Indigenous, and environmental social movement (Fisher et al., 2019; Lee Peluso et al., 2008; Moeliono et al., 2017; Sahide et al., 2020). Therefore, the local commons can also be understood as part of the national and global systems (Chikozho \& Mapedza, 2017; Saunders, 2014). Notably, the program was able to open the space to local practice commoning and therefore crafting commons. From collectively protecting their young cashew trees, they use the experience to manage collective cow range, and currently cashew nuts processing and selling.

However, while these findings might be tempting for us to see "the bright side" of the public services and governance (Douglas et al., 2021), the state programs have to negotiate and be molded by local actors and conditions in order to be successful ( $\mathrm{Li}$, 1999). Indeed, the failure of 12 other HKm groups is locally attributed to the enclosure by the dominance of tree timber in their plot and that the group members have other lands to till outside the village. The early stage of the social forestry trial project focused more on forest rehabilitation than access to the people who depend on them. The high modernist conservation plan came with 70\% timber trees and 30\% mpts devoid of local conditions, thus creating a failed scheme (Scott, 1999).

The success of the other two HKm groups lies in the relatively open space for power struggle for the people to mold and bend the scheme to their ends (Gaventa, 2006). The enclosure did not succeed on the entire $\mathrm{Hkm}$ area in Mattirotasi only because the groups, with the help of an extension worker, bent the rules and continued their activities by practicing commoning, and therefore creating a commons. Since then, they have been incrementally crafting institutions by combining adopted rules and maintaining relevant norms. The commons then successfully provide sustainable benefits to the members, producing steady income mainly from the cashew nuts and cows. Specifically, this success depends on several interrelated factors: the state protection, economic incentive, practice of commoning through 'institutional bricolages' (Cleaver \& de Koning, 2015), and inclusion of the extension worker as a cultural interpreter and information bridge.

The state looms over the area, and a formal document in ministerial decree for $\mathrm{HKm}$ grants represents the ultimate state protection. Without this document, multiple actors would lay claims on parts of the HKm area as in the past. Prior to the HKm projects and program, multiple land tenure was present in Mattirotasi. The traditional practice of claiming land cultivated by one's ancestor who first cleared the plot, sharecropping, or land deals developed after the inheritance, and modern formal Cultivation Right granted for business (HGU) was intersected and sometimes intersected overlap in the state forest in Mattirotasi. These practices were effectively ended at the beginning of the BPDAS program in 2002, and the members' land use rights became even stronger at the issue of the ministerial decree 2012. Therefore, the state has served a profound function to secure the current land tenure from different parties that come from time to time with varied claims (Ryan 2013).

From the outset, the potential economic benefit from becoming a HKm member is critical to stimulate their self-organization for collective action (Seixas \& Davy, 2007). The uncertain future of the HKm grants during the early stage serves to select 
participants, to distinguish the landless from the landed farmers. Most of the aspiring members were rural proletarians involved in casual jobs with daily wages. Then, the former members who chose to neglect their plots are landed farmers who have other plots outside the $\mathrm{HKm}$ and only intend to become absentee landowners, practicing a traditional land tenure of 'ongko', namely controlling the land without actually cultivating the plot.

The practice of commoning in Mattirotasi has been so far able to protect, preserve and create new commons. Out of the subsequent needs to protect the entire plots of the two $\mathrm{HKm}$ groups, the members began to craft rules collectively by combining new formal rules and mechanisms with traditional ones. They administer the group rule that obliges the members to weed and plant their plots to select landless landowners and set annual contributions for building and maintaining fences. Meanwhile, the traditional practices of collective works offer a multitude of opportunities to meet and talk about shared issues, which among others, create monitoring mechanisms and ensure participation. The values such as helping each other in agricultural and life cycle-related activities help uphold informal sanctions such as non-financial settlements. They even preserve the longstanding rationalities such as belief in magical powers as a monitoring tool. Through gossip, word of mouth, the information travels to the whole village and beyond, forging a shared knowledge of the groups' magic power and collective watch effectively preventing trespassers. In this way, they fulfill the dimensions of commoning social practices: co-produce institutional bricolage (Cleaver \& de Koning, 2015; Jones, 2015) in the form of local services to face several constraints, contributes voluntarily to satisfy shared needs, create self-governing institutions where members directly affecting each decision making (Euler, 2018; Fournier, 2013). When needed, they also bend the formal rules, such as planting corn to surround and protect their young cashew trees, a practice that is facilitated and tactically protected by the inclusion of an extension worker in their group.

Nevertheless, the extension worker serves so much more than just helping to bend the formal rules. He is deeply tied to and understands the local socio-cultural and political-economic contexts. He originated from a nearby village and has many close relatives in Mattirotasi. Moreover, as a regency state employee, he has contacts beyond the villages and sits in a position that enables him to provide important information and network needed by the group. Therefore, he can process the group aspirations and demands and craft them as suitable proposals to relevant state agencies at different levels and present them in the moments and manner that considers complex bureaucratic red tapes, loopholes, and opportunities.

\section{CONCLUSION}

The case shows that the state has provided necessary and basic programs and rules for creating the local commons in Mattirotasi. Meaning that the local commons cannot persist without the state's powerful protection of the current tenure and continued support. Conversely, the state policies would fail to create commons without commoning practices involving collective governance that combines different rules and rationality and even at times bending the rules to achieve shared goals. Here, it is essential to note that the inclusion of a cultural mediator or interpreter in the extension worker provides a crucial bridge, channeling aspirations, information, programs, and goods between the state and the commoners. 
This interdependence can be better understood by tracking back to the beginning when the commons was created instead of only focusing on how commons evolve and persist. Design principles have enabled us to dive into necessary elements that define a commons and its success or failure. However, standing alone, the principles may only represent a portrait of the commons at the research time. Moreover, exploring how local norms and values interact with formal rules and interests resulted in a clearer picture of how the commons incrementally crafted, preserved, and created new commons. Here, aside from the extension worker who serves as a channel, the commons success depends on the solid economic incentives, relatively autonomic space for commoning, and institutional bricolage play essential roles.

Focusing on the practice of commoning, we found that varied types of institutions, interests, and rationalities meet to cooperate or be involved in conflict with each other at different moments. Contingently, various alliances of actors or convergence of interests may change. The national political climate, for instance, may suppress demands for access to land and open an opportunity for new claimants to exclude the HKm groups out of their granted lands. Similarly, some prominent members may develop stronger connections to local political elites and use the newly acquired power to privatize parts of the commons and start the process of decommoning from below. In fact, this might provide the question for future research, what happens when there is a change related to community forestry policies, if power balance changes occur in the national and local level, how would they change the decision-making processes in the group? Another critical issue may come from below: what happens to the excluded non-members within and around the village? Seeing the steady stream of lucrative income flow from the forest, do they just stay put?

Author Contribution: Haudec Herrawan and Nurhady Sirimorok : Conceptualization, Methodology, Data collection; Analysis, Writing (draft preparation, reviewing, editing), Muhammad Alif K. Sahide: Conceptualization, Writing-draft preparation, Fatwa Faturachmat and Munajat Nursaputra: Providing map and Data collection, Andi Sadapotto, Yusran Yusran, Supratman Supratman: Content analysis

Conflict of Interest: The authors declare that they have no known competing financial interests or personal relationships that could have appeared to influence the work reported in this paper.

Acknowledgement: Thanks to Kemendikbud Ristekdikti, 2021

\section{References}

Agrawal, A., \& Gibson, C. C. (1999). Enchantment and Disenchantment: The Role of Community in Natural Resource Conservation. World Development, 27(4), 629649. https://doi.org/10.1016/S0305-750X(98)00161-2

Aspinall, E., \& van Klinken, G. (Eds.). (2011). The state and illegality in Indonesia. KITLV Press.

Baggio, J. A., Barnett, A. J., Perez-lbarra, I., Brady, U., Ratajczyk, E., Rollins, N., Rubiños, C., Shin, H. C., Yu, D. J., Aggarwal, R., Anderies, J. M., \& Janssen, M. A. (2016). Explaining success and failure in the commons: the configural nature of Ostrom's institutional design principles. International Journal of the Commons, 10(2), 417. http://doi.org/10.18352/ijc.634 
Bakker, K. (2007). The "commons" versus the "commodity": Alter-globalization, antiprivatization and the human right to water in the global south. Antipode, 39(3), 430-455. https://doi.org/10.1111/j.1467-8330.2007.00534.x

Bollier, D. (2014). The Commons as a Template for Transformation. The Great Transition Initiative. http://hdl.handle.net/10535/9300

Bollier, D., \& Helfrich, S. (Eds.). (2015). Patterns of Commoning. Commons Strategy Group and Off the Common Press.

Chikozho, C., \& Mapedza, E. (2017). In search of socio-ecological resilience and adaptive capacity: articulating the governance imperatives for improved canal management on the Barotse floodplain, Zambia. International Journal of the Commons, 11(1), 119-143. http://doi.org/10.18352/ijc.636

Cleaver, F., \& de Koning, J. (2015). Furthering critical institutionalism. International Journal of the Commons, 9(1), 1-18. http://doi.org/10.18352/ijc.605

Cox, M., Arnold, G., \& Tomás, S. V. (2010). A Review of Design Principles for Community-based Natural Resource Management. Ecology and Society, 15(4), 38. http://dx.doi.org/10.5751/ES-03704-150438

Douglas, S., Schillemans, T., 't Hart, P., Ansell, C., Bøgh Andersen, L., Flinders, M., Head, B., Moynihan, D., Nabatchi, T., O’Flynn, J., Peters, B. G., Raadschelders, J., Sancino, A., Sørensen, E., \& Torfing, J. (2021). Rising to Ostrom's challenge: an invitation to walk on the bright side of public governance and public service. Policy Design and Practice, 4(4), 441-451. https://doi.org/10.1080/25741292.2021.1972517

Ellickson, R. (1991). Order without Law: How Neighbors Settle Disputes. Harvard University Press.

Euler, J. (2018). Conceptualizing the Commons: Moving Beyond the Goods-based Definition by Introducing the Social Practices of Commoning as Vital Determinant. Ecological Economics: The Journal of the International Society for Ecological Economics, 143, 10-16. https://doi.org/10.1016/j.ecolecon.2017.06.020

Fisher, J. B., \& Nading, A. M. (2020). The end of the cooperative model (as we knew it): Commoning and co-becoming in two Nicaraguan cooperatives. Environment and Planning E: Nature and Space. https://doi.org/10.1177/2514848620901439

Fisher, M. R., Dhiaulhaq, A., \& Sahide, M. A. K. (2019). The politics, economies, and ecologies of Indonesia's third generation of social forestry: An introduction to the special section. Forest and Society, 3(1), 152-170. http://dx.doi.org/10.24259/fs.v3i1.6348

Fournier, V. (2013). Commoning: on the social organisation of the commons. M@n@gement,16(4),433-453.https://doi.org/10.3917/mana.164.0433

Gaventa, J. (2006). Finding the spaces for change: A power analysis. IDS Bulletin, 37(6), 23-33. http://dx.doi.org/10.1111/j.1759-5436.2006.tb00320.x

Hardin, G. (1968). The Tragedy of the Commons: The population problem has no technical solution; it requires a fundamental extension in morality. Science, 162(3859), 1243-1248. https://doi.org/10.1126/science.162.3859.1243

Harvey, D. (2011). The Future of the Commons. Radical History Review, 109, 101-107. http://dx.doi.org/10.1215/01636545-2010-017

Helmke, G., \& Levitsky, S. (2004). Informal Institutions and Comparative Politics: A Research Agenda. Perspectives on Politics, 2(4), 725-740. https://doi.org/10.1017/S1537592704040472 
Jones, S. D. (2015). Bridging political economy analysis and critical institutionalism: an approach to help analyse institutional change for rural water services. International Journal of the Commons, 9(1), 65-86. http://doi.org/10.18352/ijc.520

Lee Peluso, N., Afiff, S., \& Rachman, N. F. (2008). Claiming the grounds for reform: Agrarian and environmental movements in Indonesia. Journal of Agrarian Change, 8(2-3), 377-407. https://doi.org/10.1111/j.1471-0366.2008.00174.x

Li, T. M. (1999). Compromising power: Development, culture, and rule in Indonesia. Cultural Anthropology: Journal of the Society for Cultural Anthropology, 14(3), 295-322. https://doi.org/10.1525/can.1999.14.3.295

Moeliono, M., Thuy, P. T., Bong, I. W., Wong, G. Y., \& Brockhaus, M. (2017). Social Forestry - why and for whom? A comparison of policies in Vietnam and Indonesia. Forest and Society, 1(2), 78-97. http://dx.doi.org/10.24259/fs.v1i2.2484

Mosse, D. (2006). Collective Action, Common Property, and Social Capital in South India: An Anthropological Commentary. Economic Development and Cultural Change, 54(3), 695-724. http://dx.doi.org/10.1086/500034

Mudliar, P., \& Koontz, T. M. (2021). Locating power in Ostrom's design principles: Watershed management in India and the United States. Society \& Natural Resources, 34(5), 639-658. https://doi.org/10.1080/08941920.2020.1864535

Nayak, P. K., \& Berkes, F. (2021). Framing commons as a process: The rudiments of commonisation and decommonisation. In P. K. Nayak (Ed.), Making Commons Dynamic: Understanding Change Through Commonisation and Decommonisation (pp. 3-23). Routledge.

Ostrom, E. (1990). Governing the Commons: The Evolution of Institutions for Collective Action. Cambridge University Press.

Peluso, N. L. (1992). Rich Forests, Poor People: Resource Control and Resistance in Java. University of California Press.

Ryan, A. B. (2013). The Transformative Capacity of the Commons and Commoning. Irish Journal of Sociology, 21(2), 90-102. http://dx.doi.org/10.7227/IJS.21.2.7

Sahide, M. A. K., Fisher, M. R., Erbaugh, J. T., Intarini, D., Dharmiasih, W., Makmur, M., Faturachmat, F., Verheijen, B., \& Maryudi, A. (2020). The boom of social forestry policy and the bust of social forests in Indonesia: Developing and applying an access-exclusion framework to assess policy outcomes. Forest Policy and Economics, 120, 102290. https://doi.org/10.1016/j.forpol.2020.102290

Sandström, E., Ekman, A.-K., \& Lindholm, K.-J. (2017). Commoning in the periphery The role of the commons for understanding rural continuities and change. International Journal of the Commons, 11(1), 508-531. http://doi.org/10.18352/ijc.729

Saunders, F. P. (2014). The promise of common pool resource theory and the reality of commons projects. International Journal of the Commons, 8(2), 636-656. http://doi.org/10.18352/ijc.477

Scott, J. C. (1999). Seeing Like a State: How Certain Schemes to Improve the Human Condition Have Failed. Yale University Press.

Seixas, C. S., \& Davy, B. (2007). Self-organization in integrated conservation and development initiatives. International Journal of the Commons, 2(1), 99-125. http://doi.org/10.18352/ijc.24

Shaw, M. (2014). Learning From the Wealth of the Commons: A Review Essay. Community Development Journal, 49(suppl_1), i12-i20. 
https://doi.org/10.1093/cdj/bsu012

Singleton, B. E. (2017). What's missing from Ostrom? Combining design principles with the theory of sociocultural viability. Environmental Politics, 26(6), 994-1014. https://doi.org/10.1080/09644016.2017.1364150

Turner, M. D. (2017). Political ecology III: The commons and commoning. Progress in Human Geography, 41(6), 795-802. https://doi.org/10.1177\%2F0309132516664433

van Schendel, W., \& Abraham, I. (Eds.). (2005). Illicit Flows and Criminal Things: States, Borders, and the Other Side of Globalization. Indiana University Press. 